\title{
LOCAL FISHERMAN RESISTANCE IN KELAPA KAMPIT COASTAL AREA TOWARD OFFSHORE MINING ACTIVITIES
}

\author{
Ibrahim $^{1}$,Dwi Haryadi ${ }^{2}$, Nanang Wahyudin ${ }^{3}$ \\ ${ }^{1}$ Political Science Department, Universitas Bangka Belitung, Indonesia \\ ${ }^{2}$ Law Department, Universitas Bangka Belitung, Indonesia \\ ${ }^{3}$ Management Department, Universitas Bangka Belitung, Indonesia
}

\begin{abstract}
Tin mining activities in Belitung Island have lasted since colonialism era to this moment. In 1990s tin exploitation in Belitung was stopped as it was assessed as no longer productive. In 1999, however, the mining had massively recommenced and at the same time, tourism and fishery were being actively developed as the new economic power. Recently, tin exploitation has shifted into offshore, and since then the conflicts began to appear. Rejection actions were continuously performed by fishermen through anti offshore mining audience, demonstration and campaign in social media. One of the rejections was when production suction vessel entered Pering waters, KelapaKampit East Belitung. At the urging of local fisherman group, written agreement between East and West Belitung head regencies, as well as the special committee recommendation of East Belitung house of representative, finally the suction vessel moved out from Pering waters. This study aimed to analyze fishermen's and stakeholders' knowledge, attitude, and expectationtoward offshore mining activities. Their point of views are needed in order to obtain complete perspective regarding the positive and negative sides, whether there is the meeting point among various interests and how long this conflicts will last. It is a mixed method research between qualitative and quantitative one. Quantitative approach employed questionnaire and SPSS 20 was used to analyze the results. Data collection technique used non-probability sampling with specific characteristic, fisherman community in Pering coastal area in which the amount applied Solvin theory. Qualitative approach was used to explore various
\end{abstract}


phenomenons developing in society through interview with stakeholders related to offshore mining issues. Qualitative research was applied to explore phenomenon developing on site, either historically or contextually. Primary data was collected through interview with stakeholders in East Belitung related to the major issues raised. Based on the questionnaire results on fishermen and the interview with the related stakeholders, there were some findings. First, fishermen's knowledge about offshore mining was very limited. Second, most fishermen were agreed that offshore mining damaged ecosystem, reduced catching and disturbed tourism. Third, the expectation if offshore mining keep operating, fishermen will continuously fight for it. In stakeholder and social society level; though there is one supporting offshore mining, so far however, the majority still put their side on fishermen, tourism, and environment's interest and thus refusing offshore mining.

Corresponding Author:iim_babel@yahoo.com 


\section{Introduction}

Belitung Island is well known as Tin Island as that of Bangka in which they have experienced tin glory from time to time [1]. There is no exact number on when tin was first found and started to mine in Belitung. Based on J.J. van Sevenhoven report from Holland, in his visit in 1823 to Belitung, he had found tin nail and thus it can be said if tin has been mined at least in $17^{\text {th }}$ century. In 1850, Prince Hendrik Baron van Tuyll van Serooskerkenorganizedly submitted proposal to open tin mining in Belitung and was granted on 23 March 1852. In 1852, this business switched to Billiton Maatschappijthat established subsidiary GemeenschappelijkeMijnbouwMaatschappij(GMP) [2].

Other history document regarding tin finding in Belitung could also be quoted from the journal of John F. London in 1853 stating that "short journey for about 14 days for us was very important as the land we studied, and although it was shallow, it was found tin seeds on top layer and thus it could be concluded that this island part is as rich as the first mining business though it was performed as an experiment" [3].

In Belitung, tin glory in the past can be seen through the historical buildings available at this moment, in Manggar, TanjungPandan, and Gantung. Tin exploitation in the past ended in 1990. PT Timah suggested that tin production in Belitung had reduced and thus it must be moved to Bangka, and there would be company employees' reduction as a result of this policy. In 1999, non-conventional, massive mining activity as a result of central government policy was also occurred in Belitung Island. Hundreds of illegal mining popped up as well as leaved hundreds of ponds damaging environment $[4,5]$

As onshore tin deposit had been minimized, meanwhile the potential of offshore tin deposit was huge, and thus mining companies started to shift their exploitation area from onshore to offshore. Moreover, at this moment, it's already available more progress suction vessel technology reaching offshore tin mining compared to previous generation as the dredger. It is the offshore mining activity and its impact that have been a sensitive issue in Belitung since several years ago to this moment. While in another side, Belitung has started to develop the potential of fishery and marine tourism. This potential has been supported by the phenomenal of 'LaskarPelangi' novel by Andrea Hirata to abroad. Both sectors have been considered as more promising, sustainable, and environment friendly. As the consequence, mining sectors started to leave behind as it damaged the environment, nonsustainable, and the presence of dark experience in the past regarding tin employee rationalization in Belitung.

Apart from suction vessel and dredger, there have been also floating tin mining with the number of around 2,500. PT. Timah itself operates 11 dredgers. Some suction vessels operate by PT. Timah counterparts. All offshore mining activities have thrown away their hundred tons waste as sand and mud and thus it becomes sediment covering coral reef, algae habitat, and 
other marine biota. Bangka Belitung University study results suggested that $50 \%$ of coral reef in Bangka waters is damaged resulted from sedimentation. Offshore mining mostly operates in the area 5 miles from the beach. It is the small fisherman catching area. Daily fishermen are the most affected by marine ecosystem resulted from this mining.

The conflict of interest among miner, fisherman, and tourism as a result of offshore mining has repeatedly occurred not only in Belitung but also in Bangka. In 2015, in PT. Timah socialization related to production suction vessel operation planning on Matras beach, there were more rejections from fishermen as it was considered as damaging. Still in the same year, thousands of fishermen came to Governor Office to refuse suction vessel since fishermen catching dramatically dropped. In West Bangka, Belo Laut citizen also refused suction vessel and production suction pontoon operation. The fisherman also held demonstration in PT. Timah Office, Belinyu marine unit to refuse offshore mining in Kelabat. Offshore mining rejection action by fishermen recently occurred was conducted by South Bangka fishermen who held the demonstration in Local Police Office and PT. Timah.

In Belitung, October 2012, fisherman community came to Belitung Head Regency Office to sign the offshore mining exploration permission revocation. In local government level itself, there had been an agreement between East and West Belitung Head Regency regarding offshore mining that was then followed up by delivering a letter to Governor. RustamEffendie, a senior tourism actor, regretted offshore mining, considering that tourism has been proved to create employment. In the grass root level, people put their signature to support offshore mining rejection in Belitung Island in NyiurMelambai beach, Manggar East Belitung.

One of offshore mining rejections by fisherman occurred in Pering waters, Mayang village, KelapaKampit that became the focus in this study. They felt threatened by the existence of suction vessel. Many efforts have been conducted by local fishermen, starting from dialogue, demonstration, and even to the extreme effort such as burning the suction vessel. In addition, it collectively raised resistance effort through the appearance of FORTTAL (Forum Rakyat Tolak Tambang Timbang/Tin Mining Resistance People Forum) supporting people's struggle. East Belitung Local Government itself, in accordance to their political promise during their last campaign, assertively refused offshore mining. Belitung House of Representatives even created a special committee for it. This paper was eager to explore how actually local fishermen community resistance was, particularly in Mayang village in which its coastal area has become the IUP coordinate point and there was also rejection on vessel suction that would be operated. There are three basic items measuredin this paper: local concept knowledge, attitude, and expectation of fishermen and stakeholders as well as social society on offshore mining activity. 


\section{Methodology}

This study applied mixed method between qualitative and quantitative study. Though different, both type of this study can fill each other [6]. This study type was used in considering of the wider information needed to formulate various phenomenon develop in the field, either historically or contextually. Therefore it will observe, take a close look and directly interact with natural setting [7]. Primary data was collected through interview with stakeholders in East Belitung related to the issues raised, such as Marine and Fishery Services, All Indonesian Fisherman Association (HimpunanNelayanSeluruh Indonesia/HNSI), Indonesian Marine and Fishery Institution, Tin Mining Resistance People Forum, and coastal village apparatus.

Quantitative approach was employed to measure fisherman community perspective, especially in Mayang village reacting on suction vessel presence. Based on KelapaKampit in Number of 2017, there were 195 Mayang people working as fisherman, and by using Solvin theory, it could be included 67 fisherman respondents being able to represent the population. However in execution, it was included 70 respondents. Questionnaire with question was organized in likert scale through descriptive approach measuring three variables: knowledge, attitude, and expectation toward offshore mining. SPSS 2.0 was applied to analyze questionnaire result data. Data collection technique was performed by non-probability sampling system and quota sampling with special characteristic, fisherman community.

\section{Discussion}

The discussion with fisherman resistance toward offshore mining began from descriptive analysis into substance. Fisherman was first described regarding age, gender, and others to see the fisherman profile that would be the major object of this study. Its perception was then about knowledge, attitude and their expectation toward offshore mining. Lastly, it was delivered description on stakeholder and local social society point of view.

\subsection{Fisherman Profile}

Fisherman profile was a short description regarding age, gender, population status, education level, length to be fisherman, and have they ever mined. This profile was important to know and understand fisherman character that would influence its perception on the knowledge of its context, attitude, and future expectation. 
Table 1. Age

\begin{tabular}{|cc|c|c|c|c|}
\hline & $\begin{array}{c}\text { Frequen } \\
\text { cy }\end{array}$ & Percent & $\begin{array}{c}\text { Valid } \\
\text { Percent }\end{array}$ & $\begin{array}{c}\text { Cumulative } \\
\text { Percent }\end{array}$ \\
\hline Valid & $<21$ yo & 1 & 1.4 & 1.4 & 1.4 \\
& $21-30$ yo & 13 & 18.6 & 18.6 & 20.0 \\
& 31-40 yo & 20 & 28.6 & 28.6 & 48.6 \\
& $41-50$ yo & 21 & 30.0 & 30.0 & 78.6 \\
& >50 yo & 15 & 21.4 & 21.4 & 100.0 \\
Total & 70 & 100.0 & 100.0 & \\
\hline
\end{tabular}

Table 2. Gender

\begin{tabular}{|c|c|c|c|c|}
\hline & Frequency & Percent & $\begin{array}{c}\text { Valid } \\
\text { Percent }\end{array}$ & $\begin{array}{c}\text { Cumulative } \\
\text { Percent }\end{array}$ \\
\hline Valid Male & 70 & 100.0 & 100.0 & 100.0 \\
\hline
\end{tabular}

\begin{tabular}{|c|c|c|c|c|c|}
\hline \multicolumn{2}{|c|}{ Table 3.Education Level } \\
\hline \multicolumn{2}{|c|}{} & $\begin{array}{c}\text { Frequenc } \\
\mathrm{y}\end{array}$ & Percent & $\begin{array}{c}\text { Valid } \\
\text { Percent }\end{array}$ & $\begin{array}{c}\text { Cumulative } \\
\text { Percent }\end{array}$ \\
\hline $\begin{array}{c}\text { Vali } \\
\mathrm{d}\end{array}$ & $\begin{array}{c}\text { Elementary } \\
\text { School }\end{array}$ & 21 & 30.0 & 30.0 & 30.0 \\
\cline { 2 - 6 } & $\begin{array}{c}\text { Junior High } \\
\text { School }\end{array}$ & 19 & 27.1 & 27.1 & 57.1 \\
\cline { 2 - 6 } & $\begin{array}{c}\text { Senior } \\
\text { High } \\
\text { School }\end{array}$ & 30 & 42.9 & 42.9 & 100.0 \\
\cline { 2 - 6 } & Total & 70 & 100.0 & 100.0 & \\
\hline
\end{tabular}

Table 4. Population

\begin{tabular}{|lc|c|c|c|c|}
\hline & $\begin{array}{c}\text { Frequenc } \\
\text { y }\end{array}$ & Percent & $\begin{array}{c}\text { Valid } \\
\text { Percent }\end{array}$ & $\begin{array}{c}\text { Cumulative } \\
\text { Percent }\end{array}$ \\
\hline Valid & Local & 66 & 94.3 & 94.3 & 94.3 \\
& $\begin{array}{c}\text { New } \\
\text { comer } \\
\text { Total }\end{array}$ & 4 & 5.7 & 5.7 & 100.0 \\
\hline
\end{tabular}


Table 5. Length to be Fisherman

\begin{tabular}{|c|c|c|c|c|c|}
\hline & & $\begin{array}{c}\text { Frequenc } \\
\mathrm{y}\end{array}$ & Percent & $\begin{array}{c}\text { Valid } \\
\text { Percent }\end{array}$ & $\begin{array}{c}\text { Cumulative } \\
\text { Percent }\end{array}$ \\
\hline \multirow{6}{*}{$\begin{array}{c}\text { Vali } \\
\text { d }\end{array}$} & $<10$ yo & 7 & 10.0 & 10.0 & 10.0 \\
\hline & $\begin{array}{c}10-20 \\
\mathrm{vo}\end{array}$ & 36 & 51.4 & 51.4 & 61.4 \\
\hline & $\begin{array}{c}21-30 \\
\text { уо }\end{array}$ & 19 & 27.1 & 27.1 & 88.6 \\
\hline & $\begin{array}{c}31-40 \\
\text { yo }\end{array}$ & 5 & 7.1 & 7.1 & 95.7 \\
\hline & $>40$ yo & 3 & 4.3 & 4.3 & 100.0 \\
\hline & Total & 70 & 100.0 & 100.0 & \\
\hline
\end{tabular}


Table 6. Having Ever Activated as Miner

\begin{tabular}{|cc|c|c|c|c|}
\hline & & $\begin{array}{c}\text { Frequenc } \\
\mathrm{y}\end{array}$ & Percent & $\begin{array}{c}\text { Valid } \\
\text { Percent }\end{array}$ & $\begin{array}{c}\text { Cumulative } \\
\text { Percent }\end{array}$ \\
\hline Valid & Yes & 7 & 10.0 & 10.0 & 10.0 \\
& No & 63 & 90.0 & 90.0 & 100.0 \\
& Total & 70 & 100.0 & 100.0 & \\
\hline
\end{tabular}

Based on Table 1 above, it could be seen that most fishermen becoming respondents were between 31 and $<50$ years old, $88 \%$ or 56 fishermen of total 70 respondents. There were only $18 \%$ or 13 fishermen were between 21 and 30 years old. Looking at the age side, the fishermen were mostly married with family economy burden. Based on Table 2, fisherman gender was all male who became the family backbone. Within education context, based on Table 3, 43\% or 30 fishermen were senior high school graduation. There were then 21 and 19 fishermen respectively graduating from elementary school and junior high school. With maximum senior high school graduation, even there were junior high school and elementary school certificate holder, it made them having minimum skill to look for other profession. Hence, it was normal for them to refuse suction vessel, since they considered that it would disturb their only economical source. 
From the demographic aspect, whether they were as local people or new comer. Based on Table 4, most fishermen of 66 people (94\%) were local people who were born or have already long settled in Mayang village. There were only 4 fishermen as new comer. They were dominantly local people, indirectly having onward and inward connection with their land of birth or the place they lived and grew up. Local people felt to have responsibility to preserve their marine quality, their beach beauty as well as wealth of fish resources and others that during this time had been enjoyed since they were born.

Based on Table 5, there were 36 people $(51 \%)$ having profession as fisherman for years. There were 19 people $(27 \%)$ as fisherman at the age of $21-30$ years old. The rest were working for less than 10 years ( 7 people), and in contrast, there were 3 people working as fisherman for more than 40 years. This data showed that most respondent profession was fisherman for ten of years who made ocean as the family economy resource. It means that it's not easy to shift their profession into other sectors, or just giving compensation from their mining production. Thus, fisherman was not only profession but also the obligation attached to them to preserve the ocean. Meanwhile, the question as they have ever mined during fishing, based on Table 6, of 70 fishermen, 63 (90\%) stated that they had never mined, only 7 $(10 \%)$ people who had ever mined, and that's the onshore mining not the offshore one. Meaning that in path with the length they mined (Table 5), majority fishermen in Mayang village truly made fisherman as their major profession and family economy source, although mining activity was sometimes tempting. In Kampak West Bangka coast, for example, research result showed the average earnings per month from mining could be twice more compared to catching fish [8].

\subsection{Context Knowledge}

Table 7.Offshore Mining Permitted as Regulation

\begin{tabular}{|l|c|c|}
\hline Alternative & Frequency & Valid Percent \\
\hline Totally do not Know & 24 & 34.3 \\
Do not Know & 44 & 62.9 \\
Know & 2 & 2.9 \\
Total & 70 & 100.0 \\
\hline
\end{tabular}


Table 8.Very Big Contribution of Offshore Mining

\begin{tabular}{|cl|c|c|}
\hline Alternative & Frequency & Valid Percent \\
\hline Valid & Totally do not Know & 20 & 28.6 \\
& Do not Know & 48 & 68.6 \\
& Know Much & 2 & 2.9 \\
& Total & 70 & 100.0 \\
\hline
\end{tabular}

Table 9. Village People Depend on Ocean

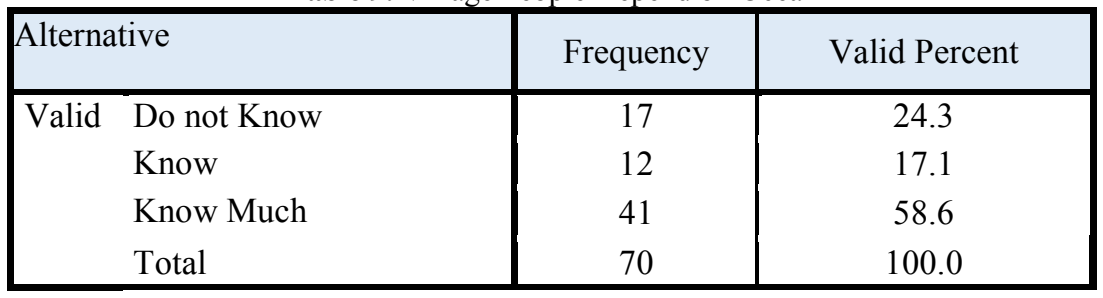

Table 10.Some People's Group Supporting Offshore Mining

\begin{tabular}{|cl|c|c|}
\hline Alternative & Frequency & Valid Percent \\
\hline Valid & Know & 7 & 10.0 \\
& Know Much & 63 & 90.0 \\
& Total & 70 & 100.0 \\
\hline
\end{tabular}

Based on Table 7, fisherman community had minimum knowledge and understanding that offshore mining could be permitted if fulfilling the requirements. There were $24(34 \%)$ fishermen who stated that they totally didn't know and $44(63 \%)$ fishermen didn't know. There were only 2 fishermen knowing it. This very limited knowledge had become the high cause factor of fisherman resistance on offshore mining activity. The fisherman knowledge itself regarding the great offshore mining contribution for the territory was illustrated in Table 8 . There were 20 fishermen stated totally not knowing, 48 not knowing, and only 2 fishermen stated knowing it. The high percentage of fishermen who didn't know it indicated the minimum information about offshore mining contribution. Based on Table 9, it could 
be seen that majority fishermen, $63(90 \%)$, were very dependent on ocean in terms of their livelihood. This data was in accordance with fisherman profile as the length to be fisherman and the very limited number for them who ever worked as miner. Thus, local people were truly having profession as fisherman and their livelihood.

The presence of offshore mining becoming pros cons issue had indeed emerged the difference on attitude and opinion in the community itself. Based on Table 10, fishermen knew and understood that there were other community groups also supporting offshore mining. There were 41 (58\%) fishermen answering knowing much, and 12 fishermen suggested to know it. This data suggested that fishermen were actually aware if there were some local people beyond them supporting offshore mining and also conducting some efforts to make it happen.

\subsection{Miner Attitude}

Table 11.Community is Involved in Offshore Mining Permission Socialization

\begin{tabular}{|ll|c|c|}
\hline \multicolumn{2}{|l|}{ Alternative } & Frequency & Valid Percent \\
\hline Valid & Agree & 17 & 24.3 \\
& Totally Agree & 53 & 75.7 \\
& Total & 70 & 100.0 \\
& & \\
\hline
\end{tabular}

Table 12.Offshore Mining Damaged Coral Reef

\begin{tabular}{|ll|c|c|}
\hline \multicolumn{2}{|l|}{ Alternative } & Frequency & Valid Percent \\
\hline Valid & Do Not Agree & 1 & 1.4 \\
& Agree & 2 & 2.9 \\
& Totally Agree & 67 & 95.7 \\
& Total & 70 & 100.0 \\
\hline
\end{tabular}


Table 13.Offshore Mining Reducing Fisherman Catching

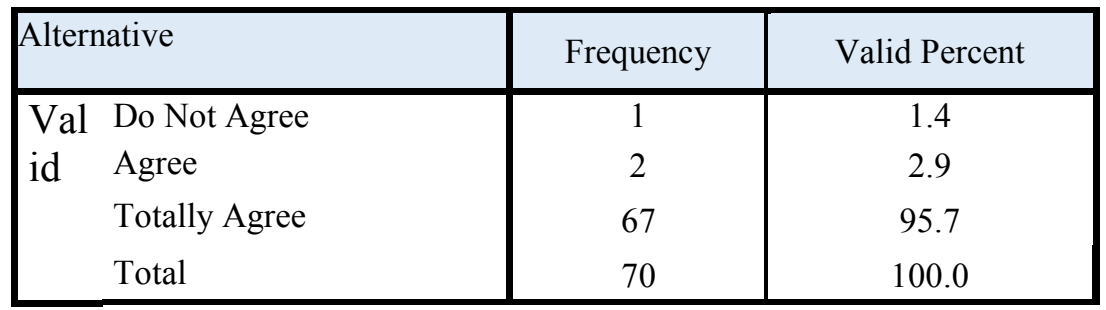

Table 14.Offshore Mining Disturbing Marine Tourism Development

\begin{tabular}{|ll|c|c|}
\hline Alternative & Frequency & Valid Percent \\
\hline Valid & Agree & 9 & 12.9 \\
& Totally Agree & 61 & 87.1 \\
& Total & 70 & 100.0 \\
\hline
\end{tabular}

Table 15.Offshore Mining is Difficult being Side by Side with Fisherman Activity

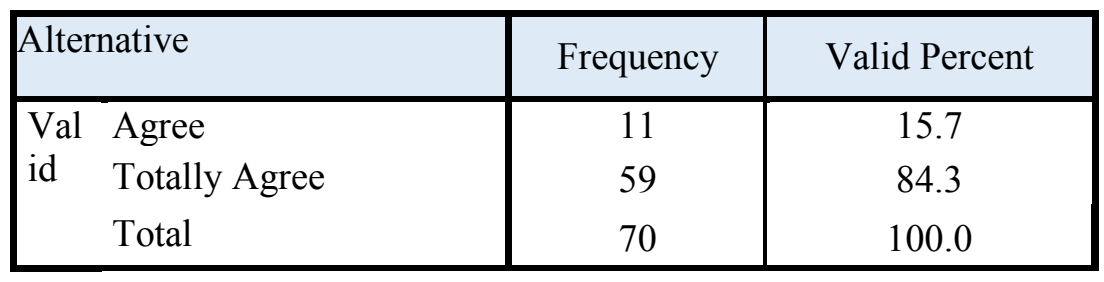

Table 16.Offshore Mining Only Benefit Small Number of People

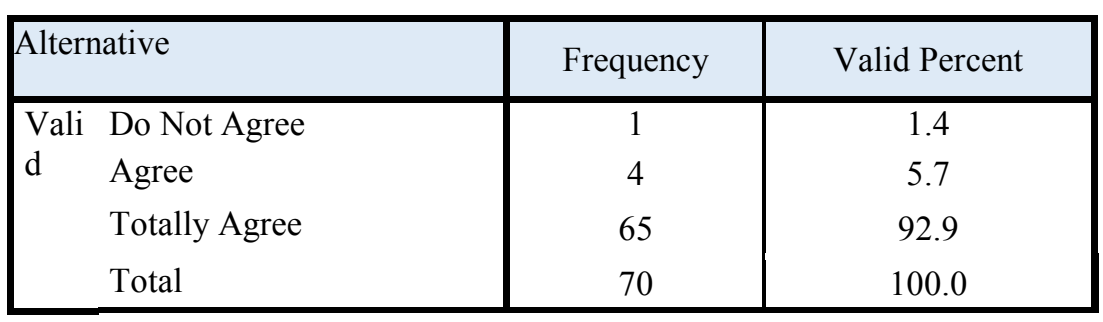


Table 17.Offshore Mining is Banned and Dealt With Firmly

\begin{tabular}{|c|c|c|}
\hline Alternative & Frequency & Valid Percent \\
\hline $\begin{array}{ll}\text { Val } & \text { Do Not Agree } \\
\text { id } & \text { Totally Agree } \\
& \text { Total }\end{array}$ & $\begin{array}{c}1 \\
69 \\
70\end{array}$ & $\begin{array}{c}1.4 \\
98.6 \\
100.0\end{array}$ \\
\hline
\end{tabular}

The question in these indicators wanted to explore as how actually fisherman attitude toward the issues related to offshore mining. Based on Table 11, there were 53 (75\%) fishermen who were totally agree if in the offshore mining permission proposal process, they were involved in socialization and thus it could be explained about its mining process, what efforts performed to prevent the impacts. Therefore, fisherman community was actually available to get involved and dialogued. Likewise, within the dialogue the company needed to hear fisherman opinion and input in order to guarantee the good and proper offshore mining, and thus there wouldn't be any conflict of interest between fisherman and miner.

One of offshore mining impacts is damaging coral reef, and it was justified by fisherman based on Table 12. There were 67 (97\%) fishermen stating that offshore mining was truly damaging coral reef. This got along with previous research performed by Coral Reef Exploration Team in several points throughout offshore mining in Bangka. Most fishermen also stated that offshore mining had impact on the fishermen catching reduction. On Table 13, there were 67 (97\%) fishermen suggested that offshore mining diminishing their catching. In accordance with the survey result, research by Nurcahya and Agustina [9] that offshore mining had reduced water quality as total dissolved solid increased and $\mathrm{pH}$ decreased; the changing on sea floor had caused the changing of flora, fauna, and plankton diversity and the increased of coral reef and fish mortality index related to them. The number of fish caught in offshore mining location was also decreased.

In terms of tourism development disturbance, in Table 14, there were 61 (87\%) fishermen who were totally agree with it. The rest $13 \%$ said agree. It means that most fishermen were agree that offshore mining would definitely 
disturb marine tourism development that had become the major potential in Belitung. Related to tourism development, the greatest challenge for government and society were that are we able to shift economy backbone from mining basis to tourism basis, and can we become an example for developing a good tourism without waiting for the ending of mining activity [10]. "LaskarPelang" booming must be the tourism revival moment, and thus it must be supported by every development sector [11].

Fishermen society negative response toward offshore mining above in turn came to the perspective that offshore mining was difficult to get along with fisherman activity and tourism development. This could be seen from Table 15 that there were 59 (84\%) fishermen suggested totally agree, and the rest suggested disagree. This majority opinion illustrated the rejection toward offshore mining activity. The rejection attitude, apart from impact factor, was also caused by offshore mining production that was only enjoyed by some people. Based on Table 16, 65 (93\%) stated such thing. Along this time, tin economy had capitalist nuance in which the capital owner gained the most profit [12]. Whereas in UNCLOS 1982, the fisherman within archipelago country has traditional fishery rights [13]. It means that fisherman is actually the ocean owner and thus their interest must be prioritized. Finally, in accordance with Table 17, 69 (98.6\%) fishermen suggested that the mining should be forbidden and firmly dealt.

\subsection{Miner's Expectation}

Table 18. The Attitude if Offshore Mining Keep Existing

\begin{tabular}{|ll|c|c|}
\hline \multicolumn{2}{|l|}{ Alternative } & Frequency & Valid Percent \\
\hline Valid & Protest Action & 34 & 48.6 \\
& Massively Resist & 36 & 51.4 \\
& 70 & 100.0 \\
\hline
\end{tabular}

Table 19. The Form of Resistance Performed

\begin{tabular}{|l|l|c|c|}
\hline \multicolumn{2}{|l|}{ Alternative } & Frequency & Valid Percent \\
\hline \multirow{3}{*}{ Valid } & Dialogue & 7 & 10.0 \\
\cline { 2 - 4 } & Demonstration & 46 & 65.7 \\
\cline { 2 - 4 } & Violence if needed & 17 & 24.3 \\
\cline { 2 - 4 } & Total & 70 & 100.0 \\
\hline
\end{tabular}


Expectation indicator aimed to directly find out fisherman attitude related to the offshore mining existence. Related to the expectation if offshore mining keep existing, the data was rather balance in which $34(48.6 \%)$ fishermen chose to have protest action and there were $36(51.4 \%)$ fishermen choosing to massively oppose. Both data showed that fisherman would not keep silent and kept making resistance with various approaches, either through protest action or massively resist. Toward the choice of massively resist, there were more than $46(65,7 \%)$ fishermen choosing to make demonstration. There were only $7(10 \%)$ fishermen choosing to have dialogue and there were at least $17(24,3 \%)$ fishermen who would commit violence if needed. Here, it could be seen the effort to resist that would be performed by fisherman community if offshore mining remain permitted. This must certainly get attention from local government and all related parties in making decision in association with offshore mining in order that no party will be lost or even victimize. The environment conflict occurred between fisherman and mining company has two character, they are open and latent. Open character is conducted by protest action, dialogue until demonstration, while the latent one occurred as the mining keeps operating and the society obtains incomparable compensation to things they have experienced. Furthermore, latent conflict can also be happened between fisherman and the organization they work in, such as HNSI. Therefore, the fishermen can be then split, some believe to HSNI and some other doesn't believe much on HSNI [14].

\subsection{Greatest Expectation}

Fisherman expectation could also be seen from their greatest hope that could be classified into several offshore mining rejection augmentations: economy, environment, and tourism aspect. In economy aspect, some fishermen stated that marine is their life source in which their dependency on it is very high, as the only family income source, and mining will definitely diminish revenue and thus their life will be getting more difficult. The statement from one of the fishermen, Mh submitted: "Our life is greatly dependent on ocean and thus it must be preserved and free from mining." As was then stated: "If there is suction vessel, there must be followed by small offshore miner. Ocean will be more damaged and our livelihood will be more difficult." In the environment aspect, fisherman suggested that offshore mining would damage coral reef, hence making it difficult to catch fish. Therefore, they refused suction vessel. For fisherman, ocean is the legacy for their children and grand children later, thus it must not be ever damaged. Af said: "Marine damaged by suction vessel is not worth it with its result, thus we must preserve it." Bd said: "Mining waste will cover coral reef as the home for fish." The research result in South Bangka showed that the content of $\mathrm{Pb}$ and $\mathrm{Fe}$ within ocean water in tin mining area was higher than that of outside it and the quality threshold for it was $0.08 \mathrm{mg} / \mathrm{L}$. This substance is absorbed by squid body and on the higher level, it will be poisonous and influence the stock deposit and in turn have impact on squid fishing area. 
There was $\mathrm{Pb}$ heavy metal bioaccumulation within squid gill, $1.771 \mathrm{mg} / \mathrm{L}$ [15].

Third, the fishermen's greatest expectation related to offshore mining rejection was the big dream on the tourism progress as the future sustainable mainstay sector. The sustainable development principal itself does need the environment law awareness [16] and this had been possessed by the fishermen. Dh, for example, conveyed that offshore mining would disturb marine tourism. Yl then stated to make ocean as marine tourism. There was also Fe who asserted that Belitung ocean is famous with marine tourism, but not with offshore mining. In addition to the three expectations above, some fishermen also explicitlyexpressed their hope to the government in order to be more concern on tourism sector and minor fishermen fate rather than thinking about offshore mining in that its destruction would be difficult to overcome. Although law politic of natural resources domination is firmly asserted in constitution; however, their management resulted in injustice and nationally mining exploitation didn't also deliver prosperous to society [17]

\subsection{Offshore Mining, Between Pros and Cons}

Offshore mining rejection in East Belitung, especially by fishermen in KelapaKampit reaping pros and cons was actually not only disharmony among fishermen, tourism actors, and mining companies. However it's more than that, pros cons attitude, supporting and not supporting, agree and disagree also involved many parties either formally or informally, politically or non-politically. Politically, East and West Belitung Head Regency had agreed together to reject offshore mining. On the urging of fisherman union, East Belitung House of Representatives finally made Special Committee in association to the rejection of fisherman society in Pering waters Mayang Village in terms of KM Kamilah suction vessel presence that already operated in its IUP OP coordinate. The Special Committee issued several recommendations: first, asking local government to evaluate IUP and to Province Government to revoke and order to pull Kamilah suction vessel out of East Belitung water; second, in issuing permission in East Belitung Regency, Province Government should involve local government; third, asking Province Government and Provincial House of Representatives in discussing RZWP3K Local Regulation Meeting especially for East Belitung Regency to involve and ask input from stakeholder and community elements in East Belitung Regency; fourth, asking to Province Government through East Belitung Head Regency in order that there wouldn't be any mining activity in East Belitung ocean territory before Local Regulation regarding Zones Planning on Coastal Area and Small Islands was set; and the last, Special Committee agreed to refuse KIP presence and reject offshore mining in East Belitung water territory. This Special Committee recommendation showed House of Representatives partiality on fisherman community and tourism development.

Apart of Head Regency and House of Representatives, East Belitung Marine and Fishery Agency also agreed that offshore tin mining would 
impact on ocean ecosystem damage and fisherman catching area reduction. Zulfi who works on PNKPWP in DKP stated that the technology owned by KIP had not been able to minimize ocean ecosystem damage, and thus reducing fisherman catching area. No matter how big the offshore mining will be, it will always be non-sustainable in nature. Therefore, it will be better to prioritize tourism and marine fishery sector development that is sustainable in nature. Do not only calculate the economical profit, but it must also count the ecological lost value. East Belitung itself has proposed zero offshore mining to province and up to this moment this local regulation draft regarding zones hasn't been finalized.

Offshore mining problem from the perspective of East Belitung vice chief of All Indonesian Fisherman Association, MulyaKaryadi, had different opinion. According to him, maritime resource was not merely fish, shrimp, squid, and others, but also mining materials; moreover, if the minerals were as tin metal and the mineralcontaminant widely needed in industrial world. Therefore, the potential must be maximized in order to accelerate local development. It must be admitted that recently local government needs lots of fund, rather than striving to invite uncertain investors, it is better to permit offshore tin mining to operate as the revenue obtained is already obvious. The concept will be asking $10 \%$ revenue sharing and thus it will be expected around 20 trillion rupiah. The fund will accelerate development in all sectors, such as fish processing industry, tourism industry, and other programs supporting fisherman's and tourism actors' prosperity. There will always impact as the consequence of mining; however, the solution must be found out, but not just reject without solution. For example: tailing should not directly throw away to ocean without processing. We have ways or recent technology and environmental friendly, hence among offshore mining, tourism, and fisherman activities can run in harmony.

While from the village apparatus side, Mentawak head village, BapakDaerobi whose some of his citizens have profession as fisherman, seeing this offshore mining rejection as a result of several things. First, the benefit could not be enjoyed by people in general. Second, past disappointment when the tin was stated as run out so that there was employees cut off. Third, they were not willing if their ocean was destroyed as the ocean potential such as squid, and fish, and most of them were small fisherman. Fourth, as this time local people along with government are focusing on tourism program, and tourism aware group formation. There are then the compensation offered that will not influence people's rejection, since the community has already been comfortable with the ocean condition that has become their revenue expectation.

Indonesian Marine and Fishery Institution of East Belitung led by MukhaediMachwari stated that as an institution, they definitely rejected offshore mining, even we along with fisherman and local government have made letter to central government, since offshore mining will damage ocean ecosystem, fish breeding, turbid and muddy water as well as other damages. However, personally, I have other opinion. By seeing the minimum tourism 
infrastructure, the economy development remaining dependent on tin, and local government fund limitation, therefore for the sake of larger benefit and fisherman interest, tin mining should be permitted with special control and restrictions and responsibility; started from its processing, area permission, environmental friendly technology application, supervision and much involving local people, compensation improvement for local government and local people minimum $10 \%$, as well as special compensation for directly impact society. The presence of offshore mining in East Belitung has produced social society power. One of them is People Forum for Refusing Offshore Mining led by Mr. Albani. This institution was founded as a result of citizen desire (fisherman, employee, and general people) to firmly refuse offshore mining. It doesn't believe on guarantee that offshore mining will not damaging. Dredge/suction vessel operates in fisherman fishing area must be disturbing much. The rejection was also caused by past disappointment of many former tin company employees. The compensation offered will not be comparable with the ocean damaged caused. Meanwhile many people depends their life on ocean. We are willing to support if there is really available the environmental friendly technology, however it should be shown and socialized to citizen. Environmental or ocean friendly suction vessel technology availability can actualize what was stated by Sudrajat [18] as good and green practice mining.

\section{Conclusion}

Resistance or fisherman rejection in Pering waters toward offshore mining has been very great. There were several reasons: first, the minimum socialization on offshore mining operation, the contribution and technology employed, as well as the efforts to overcome the impact; second, offshore mining, according to fishermen would destroy coral reef, diminish fisherman catching area and in turn decrease their income that depended a lot on ocean; three, offshore mining would disturb tourism development that had just begun; fourth, the offshore mining product would not be comparable with the marine damage caused, non-sustainable and only enjoyed by a small number of people; fifth, there hadn't been any environmental friendly offshore mining technology, including the proper reclamation pattern. While local government, house of representative, and the stakeholder, as well as social society, mostly had similar opinion with the fishermen to refuse offshore mining.

Thank you to the Directorate of Research and Community Service that has funded this research in the scheme of 2018 Competency Grant. 


\section{Reference}

1 Bahari U. 2015.Bangka Tin Magnet from Time to Time. In Bangka History Seething. Bangka: Bangka Regency Culture and Tourism Agency

2 Sujitno S. 2007.The Impact of Indonesian Tin Presence along the History. Jakarta: Cempaka Publishing, Jakarta.

3 Kurniawan W. 2016.The Last 'Kulek' (An Introduction to SawangGantong Tribe History). Manggar: LPMP Air Mata Air

4 Haryadi D.2014.Illegal Tin Mining (Life Time Problem?), In: After 14 years (The Journey Note of Bangka Belitung Islands Province). Yogyakarta: Imperium

5 Haryadi D.2015.Criminogen Factor of Illegal Tin Mining in Bangka Belitung. Law Problems Journal UNDIP Vol 44 No 1.

6 Sumanto 2014.Research Method Theory and Application, Psichology, Education, Business Economy, and Social. Yogyakarta: Center for Academic Publishing Service (CAPS)

7 Sugiyono 2009.Quantitative and Qualitative Method and $R \& D$. Bandung: Alfabeta

8 Alpharesy MA. Anna Z. Yustiati A. 2012. Revenue Analysis and Labor Fisherman Household Expenses Pattern in Kampak Coastal Area, West Bangka Regency.Marine Fishery Journal UNPAD Vol 3, No 1.

9 Nurcahya E. Agustina F. 2015.Managing the socio-economic impact of tin mining in Bangka Island, Indonesia - preparation for closure. Conference: The 10th International Conference on Mine Closure, At Vancouver June 2015.

10 Megawandi Y. 2014.Tourism Role in Bangka Belitung Islands Economy. In: After 14 Years (The Journey Note of Bangka Belitung Islands Province). Yogyakarta: Imperium

11 Zukhri N. 2015.LaskarPelangi Tourism Brandisization. Imperium: Yogyakarta

12 Ibrahim. 2013. Tin Chaos and the Stammered of Ideology Pancasila. Imperium: Yogyakarta

13 Solihin A. 2010.Marine and Fishery Law Politics (Issue, Problem, and Critical Policy Review). Bandung: NuansaAulia

14 Sari YTW.Satria A. Fisherman Access toward Coastal Resources in Mining Area.Tran discipline Journal of Sociology, Communication, and Human Ecology. Vol 05. No 03 
15 Febrianto A. Baskoro MS. Simbolon D. Haluan J. Mustarudin.The Impact of Tin Mining Activities on Squid (Uroteuthischinensis) Fishing Ground In South Bangka. International Journal of Sciences: Basic and Applied Research (IJSBAR) (2015) Volume 23, No 1, pp 283293.

16 Utomo S. Haryadi D. 2013.Mineral and Coal Mining Law. Yogyakarta: Danadiyaksa.

17 Rosadi O. 2012.Law Quo Vadis, Ecology and Social Justice. Yogyakarta: Thafa Media.

18 Sudrajat N. 2010.Indonesian Mining Theory and Practice according to Law. Yogyakarta: PustakaYustisia 